\title{
Prevalence and correlates of pre-diabetes and diabetes among a national population based sample of adults in Zambia: Results of the first national STEPS survey in 2017
}

Karl Peltzer ( $\sim$ karl.peltzer@tdtu.edu.vn )

Ton Duc Thang University

Supa Pengpid

Mahidol University

Research Article

Keywords: Diabetes, pre-diabetes, prevalence, risk factors, adults, Zambia

Posted Date: August 19th, 2020

DOl: https://doi.org/10.21203/rs.3.rs-60380/v1

License: (c) (1) This work is licensed under a Creative Commons Attribution 4.0 International License. Read Full License 


\section{Abstract}

Background: This investigation aimed to estimate the prevalence and its correlates of pre-diabetes and diabetes among 18-69 year-old persons in Zambia.

Method: Nationally representative cross-sectional data were analysed from 3,608 18-69 year old persons (31 years median age) that participated in the "2017 Zambia STEPS survey," with complete blood glucose measurement.

Results: Results indicate that $8.8 \%$ of $18-69$ year-olds had pre-diabetes and $7.2 \%$ diabetes. In adjusted multinomial logistic regression analysis, older age, rural residence, central obesity (or overweight or obesity), hypertension, raised total cholesterol and physical inactivity were associated with pre-diabetes and/or diabetes. In addition, in unadjusted analysis, female sex, lower education, alcohol family problem and alcohol dependence were associated with pre-diabetes and/or diabetes. Only $8.4 \%$ of the study sample reported that they ever had their blood glucose examined by a health care professional. Having had blood glucose measured was higher among women $(9.6 \%)$ than men $(7.2 \%)$ but not significantly $(P=0.08)$. Residents in urban areas $(11.8 \%)$ had significantly more often ever their blood glucose measured than residents in rural areas $(5.4 \%)(P<0.001)$. Among study participants with diabetes, $22.3 \%$ were aware, $9.4 \%$ were currently taking treatment and $17.1 \%$ had controlled their diabetes $(<7.0 \mathrm{mmol} / \mathrm{L})$.

Conclusion: Almost one in ten participants had pre-diabetes and diabetes and several associated variables were detected which can aid in designing intervention strategies.

\section{Background}

Non-communicable diseases are "estimated to account for $29 \%$ of all deaths in Zambia in $2016, " 1 \%$ is the mortality contribution from diabetes in Zambia. ${ }^{1}$ The World Health Organization (WHO) "estimates that diabetes was the seventh leading cause of death in 2016."2 The "global age-standardised diabetes prevalence increased from $4.3 \%$ in 1980 to $9.0 \%$ in 2014 in men, and from $5.0 \%$ to $7.9 \%$ in women." ${ }^{3}$ The "diabetes prevalence has been rising more rapidly in low- and middle-income countries than in highincome countries." ${ }^{2}$ In order to prevent and control diabetes it is important that national population-based surveys are conducted periodically. ${ }^{3}$ There is lack of national data on the prevalence of pre-diabetes and diabetes and associated factors in Zambia, a lower-middle income country in Southern Africa.

In a large community-based study among adults in 16 communities from 5 of 10 provinces in 2010 in Zambia, "the age-standardised prevalence of diabetes was 3.5\%". ${ }^{4}$ In the 2008 STEPS survey in Lusaka district, Zambia, among participants 25 years or older "the combined prevalence for impaired glucose level or diabetes was $4.0 \%,{ }^{5}$ and in an investigation of bank employees $(\mathrm{N}=121)$ in Ndola, Zambia, the prevalence of diabetes mellitus was $15 \% .{ }^{6}$ In other African countries, the national prevalence of diabetes was $5.8 \%$ in Burkina Faso, ${ }^{7} 3.3 \%$ in Ethiopia, ${ }^{8} 5.7 \%$ in Guinea, ${ }^{9} 5.6 \%$ (pre-diabetes $4.2 \%$ ) in Malawi ${ }^{10}$ and $1.4 \%$ (pre-diabetes $2.0 \%$ ) in Uganda. ${ }^{11}$ 
In several African countries, a high proportion of undiagnosed diabetes has been shown, e.g., $56 \%$ in Guinea, ${ }^{9} 70.5 \%$ in Uganda, ${ }^{12} 68.0 \%$ in Benin, ${ }^{12} 34.5 \%$ in Zambia ${ }^{4}$ and $91.7 \%$ in Burkina Faso. ${ }^{12}$ The proportion of diabetics treated and controlled has been low, e.g. $32.0 \%$ treated and $21.7 \%$ controlled in Benin, $7.3 \%$ treated and $6.9 \%$ controlled in Burkina Faso, $27.7 \%$ treated and $18.4 \%$ controlled in Kenya, and $40.1 \%$ treated and $21.4 \%$ controlled in South Africa. ${ }^{12}$

Some factors associated with the risk of type 2 diabetes, may include, as reviewed by Vonglokhan et al., ${ }^{13}$ sociodemographic factors (older age, male sex, lower education and rural or urban residence), health status (central obesity, overweight, hypertension and hypercholesterolaemia), and health risk behaviour (poor dietary pattern, sedentary behaviour, physical inactivity and substance use. In addition, psychosocial distress, such as depression, ${ }^{14}$ suicidal behaviour, ${ }^{15,16}$ stress, ${ }^{17,18}$ and passive smoking ${ }^{19}$ may be associated with pre-diabetes and/or diabetes.

The investigation aimed to estimate the prevalence and its correlates of pre-diabetes and diabetes among 18-69 year-old persons in Zambia.

\section{Methods}

Cross-sectional nationally representative data from the "2017 Zambia STEPS Survey" were analyzed. ${ }^{20}$ More details on the survey methodology and the data can be accessed; the response rate was $74.3 \%$."21 "The study was approved by the University of Zambia (UNZA) Research Ethics Committee (REC), and written informed consent was obtained from participants." 21

\section{Measures}

\section{Outcome variable: Pre-diabetes and diabetes}

Fasting ( $\geq 10$ hours) blood sugar measurements were conducted and the history of diabetes assessed (see Supplementary file 1). ${ }^{21}$ "Testing was performed using a portable rapid diagnostic device $\left(\right.$ Cardiochek $^{\text {TM}}$ ) machine which used test strips for both blood glucose and lipid profile (total Cholesterol and HDL Cholesterol)." 21 "Blood sample was collected via a minimally invasive finger prick." ${ }^{21}$ Prediabetes was defined as "fasting plasma glucose levels 6.1 to $<7 \mathrm{mmol} / \mathrm{L}$ and diabetes as fasting plasma glucose levels $\geq 7.0 \mathrm{mmol} / \mathrm{L}$, and/or currently taking insulin or oral hypoglycemic drugs and/or having been diagnosed with diabetes by a health care professional." 3

Sociodemographic information included, sex, age, work status, education, ethnic affiliation, residence status and marital status.

Psychosocial distress variables included alcohol family problem, family member died from suicide, suicidal ideation and passive smoking (details in Supplementary file 1). ${ }^{21}$ 
Health status variables included measured central obesity (Waist Circumference $>88 \mathrm{~cm}$ in females and $>102 \mathrm{~cm}$ in males); Body Mass Index (measured $<18.5 \mathrm{~kg} / \mathrm{m}^{2}$ underweight, $18.5-24.4 \mathrm{~kg} / \mathrm{m}^{2}$ normal weight, $25-29.9 \mathrm{~kg} / \mathrm{m}^{2}$ overweight and $\geq 30 \mathrm{~kg} / \mathrm{m}^{2}$ obesity); hypertension based on blood pressure (BP) measurements (average of the last two of three readings) defined as systolic BP $\geq 140 \mathrm{~mm} \mathrm{Hg}$ and/or diastolic BP $\geq 90 \mathrm{~mm} \mathrm{Hg}$ or currently on antihypertensive medication; raised total cholesterol (TC) ("fasting TC $\geq 5.0 \mathrm{mmol} / \mathrm{L}$ or currently on medication for raised cholesterol"). ${ }^{21}$

Health risk behaviour variables included daily tobacco use (smoking and/or smokeless tobacco, alcohol dependence (based on items 4-6 of the Alcohol Use Disorder Test=AUDIT; scores 4 or more), inadequate fruit and vegetable intake ( $<5$ servings/day), and based on the "Global Physical Activity Questionnaire" low, moderate or high physical activity and sedentary behaviour ( $\geq 8$ hours/day). ${ }^{21}$

\section{Data analysis}

Statistical analyses were done with "STATA software version 15.0 (Stata Corporation, College Station, Texas, USA)," taking into account the complex study design. The data were weighted "to make the sample representative of the target population (adults in Zambia aged 18 to 69 years)." 21 Unadjusted and adjusted multinomial logistic regression was used to assess predictors of pre-diabetes and diabetes (with no pre-diabetes/diabetes as reference category). Missing values were not included in the analysis. $P<0.05$ was accepted as significant.

\section{Results}

\section{Sample and diabetes status characteristics}

The sample comprised of 3,657 18-69 year old persons (31 years median age, 18 years interquartile range) with complete blood glucose measurement. More than half of the participants (61.8\%) were female, $48.0 \%$ had more than primary education, $41.0 \%$ were never married, separated, divorced or widowed, $50.4 \%$ were employed, $33.8 \%$ were Tonga by ethnicity and $64.0 \%$ lived in rural areas. More than one in seven participants (14.7\%) reported alcohol family problems, $6.2 \%$ had a close family member who died from suicide, $7.8 \%$ had past 12 -month suicidal ideation and $26.8 \%$ were exposed to passive smoking.

Almost one in four participants (22.8\%) were overweight or obese, $12.0 \%$ had central obesity, $18.8 \%$ had hypertension and $7.4 \%$ raised total cholesterol. Regarding health risk behaviours, $11.0 \%$ used tobacco daily, $7.4 \%$ were dependent on alcohol, $91.2 \%$ ate insufficient fruit and vegetables, $18.5 \%$ were physically inactive and $8.1 \%$ engaged in sedentary behaviour. Almost one in ten 18-69 year-olds had pre-diabetes (8.8\%) and $7.2 \%$ diabetes (see Table 1 ).

Associations with pre-diabetes and diabetes 
In adjusted multinomial logistic regression analysis, older age, rural residence, central obesity (or overweight or obesity), hypertension, raised total cholesterol and physical inactivity were associated with pre-diabetes and/or diabetes. In addition, in unadjusted analysis, female sex, lower education, alcohol family problem and alcohol dependence were associated with pre-diabetes and/or diabetes (see Table 2).

\section{Diabetes awareness, treatment and control}

Only $8.4 \%$ of the study sample reported that ever they had their blood glucose measured by a health care professional. Having had blood glucose measured was higher among women (9.6\%) than men (7.2\%) but not significantly $(P=0.08)$. Residents in urban areas $(11.8 \%)$ had significantly more often ever their blood glucose measured than residents in rural areas $(5.4 \%)(P<0.001)$. Among study participants with diabetes, $22.3 \%$ were aware, $9.4 \%$ were currently taking treatment and $17.1 \%$ had controlled their diabetes $(<7.0$ $\mathrm{mmol} / \mathrm{L}$ ). Awareness, treatment and control status of diabetes did not significantly differ by sex. Urban dwellers with diabetes were significantly more often aware, treated and controlled their diabetes than rural dwellers. Awareness, treatment and control of diabetes increased with age, but this was only significant for treatment of diabetes (see Table 3).

\section{Discussion}

The investigation aimed to estimate the prevalence and correlates of pre-diabetes and diabetes in a national population-based survey among 18-69 year-old persons in Zambia. The prevalence of diabetes (overall $7.2 \%, 7.5 \%$ in women and $6.9 \%$ in men) and pre-diabetes $(8.8 \%$ ) was similar among women globally $(7.9 \%)$ and lower among men globally $(9.0 \%),{ }^{3}$ and was higher than in local studies in Zambia (3.5\% diabetes ${ }^{4}$ and "impaired glucose level or diabetes" $4.0 \% 5$ ) and in Malawi (5.6\% diabetes and prediabetes $4.2 \%),{ }^{10}$ in Uganda (1.4\% diabetes and $2.0 \%$ pre-diabetes $\left.2.0 \%\right),{ }^{11}$ Burkina Faso $(5.8 \%),{ }^{7}$ Ethiopia (3.3\% diabetes) ${ }^{8}$ and in Guinea (5.7\%). ${ }^{9}$ The increased rate of diabetes found in Zambia (lowermiddle income country) may be explained by a greater change of lifestyle, older age structure and greater urbanization than in low-income other African countries (Burkina Faso, Ethiopia, Guinea and Malawi) and older studies in Zambia. ${ }^{13,22}$

The investigation showed a high prevalence of undiagnosed diabetes (77.3\%), which seems to be higher than in Guinea (56\%), ${ }^{9}$ in Uganda (70.5\%), ${ }^{12}$ in Benin (68.0\%), ${ }^{12}$ in Zambia (34.5\%) ${ }^{4}$ and lower than in Burkina Faso (91.7\%). ${ }^{12}$ The prevalence of treated diabetics in this study $(9.4 \%)$ was lower than in most other African countries, e.g. Benin (32.0\%), Kenya (27.7\%) and South Africa (40.1\%), except for Burkina Faso (7.3\%). ${ }^{12}$ The prevalence of controlled diabetes among diabetics (17.1\%) in this study was lower than in Benin (21.7\%) and South Africa (21.4\%), similar to Kenya (18.4\%) and higher than in Burkina Faso (6.9\%). ${ }^{12}$ The study found that urban dwellers had greater awareness, treatment and control of their diabetes than rural dwellers, while there were no sex differences. The lack of awareness, treatment and control among rural dwellers may be attributed to poorer health services access. "Most primary care 
facilities in Zambia do not routinely screen for cholesterol or diabetes." ${ }^{21}$ By enhancing primary facilities to conduct blood glucose tests, especially in rural Zambia, ${ }^{21}$ diabetes awareness, treatment and control may improve.

Consistent with former research, ${ }^{4,8-11}$ this investigation showed pre-diabetes and diabetes increased with age. In unadjusted analysis, the study showed that female sex was associated with pre-diabetes, but no significant sex differences were found in the adjusted analysis for pre-diabetes and diabetes. In a systematic review on sex differences of the prevalence of diabetes in Africa, in most countries no sex differences were identified. ${ }^{23}$ [Hilawe]. Rural residence and in unadjusted analysis lower education increased the odds for pre-diabetes. Some previous studies confirm the association between rural residence, ${ }^{24}$ lower education in high-income and not low- or middle-income countries ${ }^{22,24}$ and diabetes, while some other studies, ${ }^{8,25,26}$ found a higher prevalence in urban areas. A diabetes-screening programme may be introduced, particularly targeting the older age high-risk groups. ${ }^{26}$

Some studies found an association between psychosocial distress, such as suicidal behaviour, ${ }^{15,16}$ stress ${ }^{17,18}$ and passive smoking, ${ }^{19}$ increased the likelihood of diabetes, while in this study only in unadjusted analysis alcohol family problem was associated with diabetes, while the stress of family member die from suicide, suicidal ideation and passive smoking were not significantly with prediabetes and/or diabetes.

This survey found an association between hypertension, central obesity and in unadjusted analysis raised total cholesterol and pre-diabetes and diabetes. These findings are consistent with previous investigations, $4,6,8,9,11$ showing major "modifiable cardio-metabolic risk factors". ${ }^{9}$ This "combination of cardiometablic risk factors calls for a multiple rather than single risk intervention approach in this population." 13

Several health risk behaviours, such as unhealthy diet, sedentary behaviour, physical inactivity, tobacco use and alcohol misuse have been found to increase the risk for diabetes, $6,11,27-30$ while in this study only physical inactivity and in unadjusted analysis alcohol dependence were associated with pre-diabetes, and in unadjusted analysis physical inactivity was associated with diabetes, and no significant association between sedentary behaviour, daily tobacco use and inadequate fruit and vegetable intake and prediabetes and/or diabetes was found.

\section{Study limitations}

This investigation was limited because of its cross-sectional design as well as the self-report of the interview data. The variable on household income had many missing values and could therefore not be included in the analysis.

\section{Conclusion}


The study found among a nationally representative population of 18 to 69 years in Zambia that almost one in ten participants had pre-diabetes and diabetes. Less than one in five Zambians were aware, treated and controlled their diabetes. Several risk factors for pre-diabetes and/or diabetes were identified, including older age, rural residence, central obesity (or overweight or obesity), hypertension, raised total cholesterol and physical inactivity, and in unadjusted analysis female sex, lower education, alcohol family problem and alcohol dependence, which can assist in guiding interventions to prevent pre-diabetes and diabetes in the Zambian population.

\section{Declarations}

\section{Availability of data and materials}

"The data for the current study are publicly available at the World Health Organization NCD Microdata Repository (URL: https://extranet.who.int/ncdsmicrodata/index.php/catalog)."

\section{Competing interests}

The authors declare that they have no competing interests.

\section{Funding}

Not applicable.

\section{Authors' contributions}

"All authors fulfil the criteria for authorship. SP and KP conceived and designed the research, performed statistical analysis, drafted the manuscript and made critical revision of the manuscript for key intellectual content. All authors read and approved the final version of the manuscript and have agreed to authorship and order of authorship for this manuscript."

\section{Acknowledgement}

"The data source, the World Health Organization NCD Microdata Repository (URL: https://extranet.who.int/ncdsmicrodata/index.php/catalog), is hereby acknowledged."

\section{Abbreviations}

STEPS: STEPwise approach to surveillance; STATA: Statistics and data

\section{References}

1. World Health Organization (WHO) Zambia: Noncommunicable Diseases (NCD) Country Profiles, 2018. URL: https://www.who.int/nmh/countries/zmb_en.pdf?ua=1 
2. World Health Organization (WHO) Diabetes-Factsheet, 2020. URL: https://www.who.int/newsroom/fact-sheets/detail/diabetes

3. NCD Risk Factor Collaboration (NCD-RisC). Worldwide trends in diabetes since 1980:

a pooled analysis of 751 population-based studies with 4.4 million participants.

Lancet. 2016;387(10027):1513-30. doi: 10.1016/S0140-6736(16)00618-8.

4. Bailey SL, Ayles H, Beyers N, Godfrey-Faussett P, Muyoyeta M, du Toit E, Yudkin JS, Floyd S. Diabetes mellitus in Zambia and the Western Cape province of South Africa: Prevalence, risk factors, diagnosis and management. Diabetes Res Clin Pract. 2016 Aug;118:1-11. doi:

10.1016/j.diabres.2016.05.001. Epub 2016 May 7. PMID: 27485851; PMCID: PMC4994576.

5. Nsakashalo-Senkwe M, Siziya S, Goma FM, Songolo P, Mukonka V, Babaniyi O. Combined prevalence of impaired glucose level or diabetes and its correlates in Lusaka urban district, Zambia: a population based survey. Int Arch Med. 2011;4(1):2. Published 2011 Jan 12. doi:10.1186/1755-76824-2

6. Msopa E, Mwanakasale V. Identification of risk factors of diabetes mellitus in bank employees of selected banks in Ndola town. Diabetes Metab Syndr. 2019;13(2):1497-1504. doi:10.1016/j.dsx.2018.11.062

7. Millogo T, Bicaba BW, Soubeiga JK, Dabiré E, Médah I, Kouanda S. Diabetes and abnormal glucose regulation in the adult population of Burkina Faso: prevalence and predictors. BMC Public Health. 2018;18(1):350. Published 2018 Mar 13. doi:10.1186/s12889-018-5257-4

8. Animaw W, Seyoum Y. Increasing prevalence of diabetes mellitus in a developing country and its related factors. PLoS One.2017;12(11):e0187670. doi: 10.1371/journal.pone.0187670. eCollection 2017.

9. Balde NM, Camara A, Diallo AA, et al. Prevalence and awareness of diabetes in Guinea: findings from a WHO STEPS. J Endocr Metab Diabetes S Afr, 2017; 22(3): 36-42.

10. Msyamboza KP, Mvula CJ, Kathyola D. Prevalence and correlates of diabetes mellitus in Malawi: population-based national NCD STEPS survey. BMC Endocr Disord.2014;14:41. doi: 10.1186/14726823-14-41.

11. Bahendeka S, Wesonga R, Mutungi G, Muwonge J, Neema S, Guwatudde D. Prevalence and correlates of diabetes mellitus in Uganda: a population-based national survey. Trop Med Int Health.2016;21(3):405-16. doi: 10.1111/tmi.12663.

12. Manne-Goehler J, Geldsetzer P, Agoudavi K, et al. Health system performance for people with diabetes in 28 low- and middle-income countries: A cross-sectional study of nationally representative surveys. PLoS Med. 2019 Mar 1;16(3):e1002751. doi: 10.1371/journal.pmed.1002751. PMID: 30822339; PMCID: PMC6396901.

13. Vonglokham M, Kounnavong S, Sychareun V, Pengpid S, Peltzer K. Prevalence and social and health determinants of pre-diabetes and diabetes among adults in Laos: a cross-sectional national population-based survey, 2013. Trop Med Int Health. 2019;24(1):65-72. doi:10.1111/tmi.13164 
14. RoyT, LloydCE. 2012. Epidemiology of depression and diabetes: a systematic review. Journal of Affective Disorders 142(Suppl):S8-S21

15. Cheah YK, Azahadi M, Phang SN, Abd Manaf NH. Sociodemographic, lifestyle and health determinants of suicidal behaviour in Malaysia. Psychiatry Res. 2018;261:319-324. doi:10.1016/j.psychres.2017.12.086

16. Elamoshy R, Bird Y, Thorpe LU, Moraros J. Examining the association between diabetes, depressive symptoms, and suicidal ideation among Aboriginal Canadian peoples living off-reserve: a crosssectional, population-based study. Diabetes Metab Syndr Obes. 2018;11:767-780. Published 2018 Nov 22. doi:10.2147/DMSO.S184058

17. Sakakibara BM, Obembe AO, Eng JJ. The prevalence of cardiometabolic multimorbidity and its association with physical activity, diet, and stress in Canada: evidence from a population-based cross-sectional study. BMC Public Health. 2019;19(1):1361. Published 2019 Oct 24. doi:10.1186/s12889-019-7682-4

18. Surwit RS, Schneider MS, Feinglos MN. Stress and diabetes mellitus. Diabetes Care. 1992;15(10):1413-1422. doi:10.2337/diacare.15.10.1413

19. Oba S, Goto A, Mizoue T, Inoue M, Sawada N, Noda M, Tsugane S. Passive smoking and type 2 diabetes among never-smoking women: The Japan Public Health Center-based Prospective Study. J Diabetes Investig. 2020 Mar 30. doi: 10.1111/jdi.13259. Epub ahead of print. PMID: 32232941.

20. 20. World Health Organization (WHO) (2018) STEPwise approach to surveillance (STEPS). URL: https://www.who.int/ncds/surveillance/steps/en/

21. Republic of Zambia, Ministry of Health. Zambia STEPS for non-communicable disease risk factors, 2017. URL: https://www.who.int/ncds/surveillance/steps/Zambia-NCD-STEPS-Survey-Report2017.pdf?ua $=1$

22. Seiglie JA, Marcus ME, Ebert C, et al. Diabetes Prevalence and Its Relationship With Education, Wealth, and BMI in 29 Low- and Middle-Income Countries. Diabetes Care. 2020;43(4):767-775. doi:10.2337/dc19-1782

23. Hilawe EH, Yatsuya $H$, Kawaguchi L, Aoyama A. Differences by sex in the prevalence of diabetes mellitus, impaired fasting glycaemia and impaired glucose tolerance in sub-Saharan Africa: a systematic review and meta-analysis. Bull World Health Organ. 2013;91(9):671-682D. doi:10.2471/BLT.12.113415

24. Aekplakorn W, Chariyalertsak S, Kessomboon P, Assanangkornchai S, Taneepanichskul S, Putwatana P. Prevalenceof Diabetesand Relationship with Socioeconomic Status in the Thai Population: National Health Examination Survey, 2004-2014. J Diabetes Res. 2018;2018:1654530. doi: 10.1155/2018/1654530. eCollection 2018.

25. XuY, Wang L, He J, et al. Prevalenceand control of diabetes in Chinese adults. JAMA. 2013;310(9):948-59. doi: 10.1001/jama.2013.168118.

26. Latt TS, Zaw KK, Ko K, et al. Measurement of diabetes, prediabetes and their associated risk factors in Myanmar 2014. Diabetes Metab Syndr Obes. 2019;12:291-298. Published 2019 Mar 4. 
doi:10.2147/DMSO.S156270

27. World Health Organization (WHO) 2016. Global report on diabetes. Geneva, Switzerland: WHO.

28. Li M, Fan Y, Zhang X, Hou W, Tang Z Fruitand vegetableintake and risk of type 2 diabetes mellitus: meta-analysis of prospective cohort studies. BMJ Open. 2014;4(11):e005497. doi: 10.1136/bmjopen2014-005497.

29. Hamilton MT, Hamilton DG, Zderic TW. Sedentarybehavioras a mediator of type 2 diabetes. Med Sport Sci. 2014;60:11-26. doi: 10.1159/000357332.

30. Barcia JM, Flores-Bellver M, Muriach M, et al. Matching Diabetes and Alcoholism: Oxidative Stress, Inflammation, and Neurogenesis Are Commonly Involved. Mediators Inflamm. 2015;2015:624287. doi:10.1155/2015/624287

\section{Tables}

Table 1: Sample and diabetes status characteristics among 18-69 year-old persons in Zambia 


\begin{tabular}{|c|c|c|c|}
\hline \multirow[t]{2}{*}{ Variable } & Sample & Pre-diabetes & Diabetes \\
\hline & $\mathrm{N}(\%)$ & $\%(95 \% \mathrm{Cl})$ & $\%(95 \% \mathrm{Cl})$ \\
\hline \multicolumn{4}{|l|}{ Socio-demographics } \\
\hline All & 3608 & $8.8(7.7,10.1)$ & $7.2(6.2,9.4)$ \\
\hline \multicolumn{4}{|l|}{ Age (years) } \\
\hline $18-34$ & \multirow{2}{*}{$\begin{array}{l}1810 \\
(50.2)\end{array}$} & $7.8(6.5,9.3)$ & $4.4(3.3,5.8)$ \\
\hline $35-49$ & & $9.9(8.0,12.1)$ & $8.9(6.7,11.7)$ \\
\hline \multirow[t]{2}{*}{$50-69$} & $\begin{array}{l}1085 \\
(30.1)\end{array}$ & $11.5(9.0,14.7)$ & $16.8(13.6,20.5)$ \\
\hline & $713(19.8)$ & & \\
\hline \multicolumn{4}{|l|}{ Gender } \\
\hline Male & $\begin{array}{l}1379 \\
(38.2)\end{array}$ & $7.5(6.0,9.3)$ & $6.9(5.4,8.9)$ \\
\hline Female & $\begin{array}{l}2229 \\
(61.8)\end{array}$ & $10.2(8.8,11.7)$ & $7.5(6.2,9.0)$ \\
\hline \multicolumn{4}{|l|}{ Education } \\
\hline$<$ Primary & \multirow{2}{*}{$\begin{array}{l}1324 \\
(29.3)\end{array}$} & $11.5(9.6,13.7)$ & $8.0(6.4,10.0)$ \\
\hline Primary & & $10.4(8.0,13.4)$ & $7.9(5.7,10.9)$ \\
\hline >Primary & $\begin{array}{l}1424 \\
(48.0)\end{array}$ & $6.5(5.1,8.2)$ & $6.3(4.8,8.3)$ \\
\hline \multicolumn{4}{|l|}{ Marital status } \\
\hline Married/cohabiting & $\begin{array}{l}2203 \\
(59.0)\end{array}$ & $9.6(8.1,11.2)$ & $7.9(6.5,9.5)$ \\
\hline $\begin{array}{l}\text { Nev. } \\
\text { married/separated/divorced/widowed }\end{array}$ & $\begin{array}{l}1398 \\
(41.0)\end{array}$ & $7.8(6.3,9.6)$ & $6.1(4.7,7.9)$ \\
\hline \multicolumn{4}{|l|}{ Employment status } \\
\hline Employed & \multirow{2}{*}{$\begin{array}{l}1792 \\
(50.4)\end{array}$} & $8.4(7.0,10.1)$ & $7.7(6.3,9.5)$ \\
\hline Nonpaid & & $7.2(5.3,9.9)$ & $5.1(3.6,7.5)$ \\
\hline Unemployed & $\begin{array}{l}1134 \\
(29.4)\end{array}$ & $10.6(8.7,13.0)$ & $7.6(5.9,9.8)$ \\
\hline \multicolumn{4}{|l|}{ Residence } \\
\hline Urban & \multirow{2}{*}{$\begin{array}{l}1300 \\
(36.0)\end{array}$} & $5.9(4.7,7.5)$ & $7.1(5.4,9.3)$ \\
\hline Rural & & $11.4(9.7,13.3)$ & $7.3(6.1,8.6)$ \\
\hline
\end{tabular}


Ethnic group

Bemba

Tonga

Other
1048

(32.3)

1033

(33.8)

1238

(33.8)

\section{Psychosocial distress}

Alcohol family problem

Family member died from suicide

Suicidal ideation

Passive smoking

Health status

Central obesity

Body mass index

Normal

Underweight

Overweight

Obesity

Hypertension

Raised total cholesterol

\section{Health risk behaviour}

Daily tobacco use

Alcohol dependence

Fruit and vegetable intake $(<5$

servings/day)

Physical activity

Low

Moderate

\begin{tabular}{lll}
$442(14.7)$ & $8.8(6.1,12.5)$ & $10.5(7.1,15.2)$ \\
\hline $217(6.2)$ & $11.1(6.4,18.3)$ & $6.2(3.7,10.2)$ \\
\hline $286(7.8)$ & $10.5(7.0,15.4)$ & $4.6(2.8,7.5)$ \\
\hline $880(26.8)$ & $8.2(6.2,10.6)$ & $6.3(4.7,8.5)$
\end{tabular}

$501(12.0) \quad 11.3(8.2,15.3) \quad 15.0(10.6,20.8)$

2402

(70.2)

$231(6.9)$

567 (15.6)

$280(7.2)$

$8.3(7.0,9.9)$

$5.9(4.8,7.2)$

$9.5(5.9,15.0)$

$5.7(3.5,9.2)$

$9.6(7.2,12.8) \quad 11.0(7.7,15.6)$

$12.2(8.1,18.0) \quad 14.7(9.6,21.7)$

739 (18.8)

$11.1(8.8,13.8)$

$13.8(11.0,17.1)$

$333(7.4)$

$14.6(10.7$, 19.8)

$14.4(10.9,18.8)$

\begin{tabular}{llll}
\hline $389(11.0)$ & $8.2(5.4,12.3)$ & $9.4(6.6,13.2)$ \\
\hline $197(7.4)$ & $6.2(3.4,10.9)$ & $12.9(7.6,20.9)$ \\
\hline $\begin{array}{l}3045 \\
(91.2)\end{array}$ & $8.7(7.6,10.0)$ & $7.0(5.8,8.3)$
\end{tabular}

(91.2)

$706(18.5) \quad 12.4(9.5,16.0) \quad 9.0(6.7,12.1)$

$370(13.0) \quad 8.1(5.4,12.0) \quad 7.3(4.8,10.8)$ 


\begin{tabular}{clll} 
High & $\begin{array}{l}2178 \\
(68.5)\end{array}$ & $8.1(6.8,9.6)$ & $6.7(5.4,8.1)$ \\
\hline Sedentary behaviour & $312(8.1)$ & $11.5(7.7,16.9)$ & $9.2(5.9,14.2)$
\end{tabular}

Table 2: Associations with pre-diabetes and diabetes 


\begin{tabular}{|c|c|c|c|c|}
\hline \multirow[b]{2}{*}{ Variable } & \multicolumn{2}{|c|}{ Unadjusted RRR } & \multicolumn{2}{|l|}{ Adjusted RRR } \\
\hline & $\begin{array}{l}\text { Pre- } \\
\text { diabetes }\end{array}$ & Diabetes & Pre-diabetes & Diabetes \\
\hline & $\%(95 \% \mathrm{Cl})$ & $\%(95 \% \mathrm{Cl})$ & $\%(95 \% \mathrm{Cl})$ & \\
\hline \multicolumn{5}{|l|}{ Socio-demographics } \\
\hline \multicolumn{5}{|l|}{ Age (years) } \\
\hline $18-34$ & \multirow[t]{2}{*}{$\begin{array}{l}1 \\
\text { (Reference) }\end{array}$} & $\begin{array}{l}1 \\
\text { (Reference) }\end{array}$ & & $\begin{array}{l}1 \\
\text { (Reference) }\end{array}$ \\
\hline $35-49$ & & \multirow{2}{*}{$\begin{array}{l}2.17(1.39 \\
3.40)^{\star \star \star}\end{array}$} & \multirow{3}{*}{$1.23(0.84,1.80)$} & \multirow{2}{*}{$\begin{array}{l}1.64(1.06 \\
2.54)^{\star}\end{array}$} \\
\hline \multirow[t]{2}{*}{$50-69$} & $\begin{array}{l}1.37(1.03 \\
1.83)^{\star}\end{array}$ & & & \\
\hline & $\begin{array}{l}1.81(1.29 \\
2.55) \star \star \star *\end{array}$ & $\begin{array}{l}4.66(3.19 \\
6.81)^{\star \star \star}\end{array}$ & & $\begin{array}{l}3.03(2.03 \\
4.52) \star \star \star \star\end{array}$ \\
\hline \multicolumn{5}{|l|}{ Gender } \\
\hline Male & $\begin{array}{l}1 \\
\text { (Reference) }\end{array}$ & $\begin{array}{l}1 \\
\text { (Reference) }\end{array}$ & \multirow{2}{*}{$\begin{array}{l}1 \text { (Reference) } \\
1.33(0.97,1.83)\end{array}$} & $\begin{array}{l}1 \\
\text { (Reference) }\end{array}$ \\
\hline Female & $\begin{array}{l}1.40(1.07 \\
1.85)^{\star}\end{array}$ & $\begin{array}{l}1.12(0.79 \\
1.58)\end{array}$ & & $\begin{array}{l}0.86(0.54 . \\
1.37)\end{array}$ \\
\hline \multicolumn{5}{|l|}{ Education } \\
\hline$<$ Primary & \multirow{2}{*}{$\begin{array}{l}1 \\
\text { (Reference) }\end{array}$} & \multirow{2}{*}{$\begin{array}{l}1 \\
\text { (Reference) }\end{array}$} & 1 (Reference) & \multirow[t]{2}{*}{$\begin{array}{l}1 \\
\text { (Reference) }\end{array}$} \\
\hline Primary & & & $0.97(0.65,1.45)$ & \\
\hline >Primary & $\begin{array}{l}0.88(0.62 \\
1.26)\end{array}$ & $\begin{array}{l}0.97(0.64 \\
1.48)\end{array}$ & $0.74(0.51,1.10)$ & $\begin{array}{l}0.93(0.59 \\
1.45)\end{array}$ \\
\hline & $\begin{array}{l}0.52(0.38 \\
0.71)^{\star \star \star}\end{array}$ & $\begin{array}{l}0.73(0.50 \\
1.05)\end{array}$ & & $\begin{array}{l}0.93(0.63 ., \\
1.37)\end{array}$ \\
\hline \multicolumn{5}{|l|}{ Marital status } \\
\hline Married/cohabiting & $\begin{array}{l}1 \\
\text { (Reference) }\end{array}$ & $\begin{array}{l}1 \\
\text { (Reference) }\end{array}$ & - & - \\
\hline $\begin{array}{l}\text { Never } \\
\text { married/separated/ } \\
\text { divorced/widowed }\end{array}$ & $\begin{array}{l}0.78(0.59 \\
1.02)\end{array}$ & $\begin{array}{l}0.74(0.53 \\
1.04)\end{array}$ & & \\
\hline \multicolumn{5}{|l|}{ Employment status } \\
\hline \multirow{3}{*}{$\begin{array}{l}\text { Employed } \\
\text { Nonpaid } \\
\text { Unemployed }\end{array}$} & $\begin{array}{l}1 \\
\text { (Reference) }\end{array}$ & $\begin{array}{l}1 \\
\text { (Reference) }\end{array}$ & \multirow[t]{3}{*}{-} & \multirow[t]{3}{*}{-} \\
\hline & $\begin{array}{l}0.82(0.57 \\
1.19)\end{array}$ & $\begin{array}{l}0.64(0.41 \\
1.01)\end{array}$ & & \\
\hline & $\begin{array}{l}1.29(0.96 \\
1.74)\end{array}$ & $\begin{array}{l}1.01(0.72, \\
1.43)\end{array}$ & & \\
\hline
\end{tabular}


Residence

Urban

Rural

$$
\begin{array}{lll}
1 & 1 & 1 \text { (Reference) } \\
\text { (Reference) } & \begin{array}{l}
1 \\
\text { (Reference) }
\end{array} & 2.01(1.40,2.89)^{\star \star \star} \\
2.05(1.50, & 1.09(0.77, & \\
2.82)^{\star \star} & 1.56) &
\end{array}
$$

Ethnic group

Bemba

$\begin{array}{ll}1 & 1 \\ \text { (Reference) } & \text { (Reference) }\end{array}$

Tonga

Other

$$
\begin{array}{ll}
1.37(0.94, & 1.34(0.79 \\
2.01) & 2.28) \\
1.37(0.96, & 1.34(0.86, \\
1.96) & 2.10)
\end{array}
$$

\section{Psychosocial distress}

Alcohol family problem

Family member died from suicide

Suicidal ideation

Passive smoking

\section{Health status}

Central obesity

$1.52(1.01$, $2.27)^{\star}$

$1.04(0.66$,

1.62)

$1.66(1.04$ $2.64)^{\star}$

$1.21(0.75,1.95)$

$1.30(0.72$, 2.35)

0.87 (0.49, 1.55)

1.19 (0.75, 1.88)

$0.62(0.36$,

1.06)

\begin{tabular}{|c|c|c|c|c|}
\hline Normal & $\begin{array}{l}1 \\
\text { (Reference) }\end{array}$ & $\begin{array}{l}1 \\
\text { (Reference) }\end{array}$ & $\begin{array}{l}\text { Not included because of } \\
\text { overlap with central obesity }\end{array}$ & \\
\hline Overweight & $\begin{array}{l}1.16(0.67 \\
2.00)\end{array}$ & $\begin{array}{l}0.99(0.57 \\
1.70)\end{array}$ & & \\
\hline Obesity & $\begin{array}{l}1.25(0.87 \\
1.78)\end{array}$ & $\begin{array}{l}2.03(1.29 \\
3.21)^{\star \star \star}\end{array}$ & & \\
\hline & $\begin{array}{l}1.72(1.04 \\
2.82)^{\star}\end{array}$ & $\begin{array}{l}2.92(1.72 \\
4.98) * \star \star\end{array}$ & & \\
\hline lypertension & $\begin{array}{l}1.53(1.14 \\
2.06)^{\star \star}\end{array}$ & $\begin{array}{l}2.72(1.99 \\
3.73)^{\star \star \star}\end{array}$ & $1.38(0.97,1.95)$ & $\begin{array}{l}2.24(1.61 \\
3.13)^{\star \star \star}\end{array}$ \\
\hline $\begin{array}{l}\text { aised total } \\
\text { holesterol }\end{array}$ & $\begin{array}{l}2.10(1.39 \\
3.16)^{\star \star \star}\end{array}$ & $\begin{array}{l}2.61(1.80 \\
3.77)^{\star \star \star}\end{array}$ & $1.78(1.08,2.94)^{\star}$ & $\begin{array}{l}1.40(0.89, \\
2.20)\end{array}$ \\
\hline
\end{tabular}

$\left.\begin{array}{ll}0.88(0.63, & 0.82 \\ 1.22\end{array}\right)(0.56$,
$1.42(0.84$, 2.39)

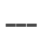

$1.90(1.20$ $3.03)^{\star \star}$

Body mass index 


\begin{tabular}{|c|c|c|c|c|}
\hline Daily tobacco use & $\begin{array}{l}0.93(0.58, \\
1.52)\end{array}$ & $\begin{array}{l}1.38(0.89 \\
2.14)\end{array}$ & - & -- \\
\hline Alcohol dependence & $\begin{array}{l}0.71(0.37 \\
1.36)\end{array}$ & $\begin{array}{l}1.98(1.07 \\
3.68)^{\star}\end{array}$ & $0.77(0.39,1.51)$ & $\begin{array}{l}1.68(0.89 \\
3.17)\end{array}$ \\
\hline $\begin{array}{l}\text { Inadequate fruit and } \\
\text { vegetable intake }\end{array}$ & $\begin{array}{l}0.97(0.61 \\
1.55)\end{array}$ & $\begin{array}{l}0.72(0.45 \\
1.15)\end{array}$ & -- & -- \\
\hline \multicolumn{5}{|l|}{ Physical activity } \\
\hline & $\begin{array}{l}1 \\
\text { (Reference) }\end{array}$ & $\begin{array}{l}1 \\
\text { (Reference) }\end{array}$ & & $\begin{array}{l}1 \\
\text { (Reference) }\end{array}$ \\
\hline \multirow[t]{2}{*}{ High } & $\begin{array}{l}0.61(0.36 \\
1.02)\end{array}$ & $\begin{array}{l}0.75(0.42 \\
1.31)\end{array}$ & $0.57(0.39,0.83)^{\star \star}$ & $\begin{array}{l}0.98(0.53, \\
1.81)\end{array}$ \\
\hline & $\begin{array}{l}0.60(0.43 \\
0.85)^{\star \star}\end{array}$ & $\begin{array}{l}0.68(0.46 \\
0.99)^{\star}\end{array}$ & & $\begin{array}{l}0.86(0.56 \\
1.32)\end{array}$ \\
\hline Sedentary behaviour & $\begin{array}{l}1.40(0.88, \\
2.24)\end{array}$ & $\begin{array}{l}1.46(0.88 \\
2.44)\end{array}$ & - & - \\
\hline
\end{tabular}

Table 3: Diabetes aware, treated and controlled $(\mathrm{N}=296)$

\begin{tabular}{|llll|}
\hline Variable & Of diabetics aware & Of diabetics treated & Of diabetics controlled $(<7.0 \mathrm{mmol} / \mathrm{I})$ \\
\hline Total & $55(22.3)$ & $28(9.4)$ & $42(17.1)$ \\
\hline Male & $23(23.4)$ & $11(9.3)$ & $16(17.2)$ \\
\hline Female & $32(21.3)$ & $17(9.5)$ & $26(17.0)$ \\
\hline P-value & 0.816 & 0.955 & 0.991 \\
\hline Residence & & & $17(9.3)$ \\
\hline Rural & $22(11.0)$ & $10(4.7)$ & $25(26.3)$ \\
\hline Urban & $33(35.7)$ & $18(14.9)$ & $<0.002$ \\
\hline P-value & $<0.001$ & $<0.004$ & $9(14.4)$ \\
\hline Age group & & $3(2.5)$ & $12(18.5)$ \\
\hline $18-34$ & $11(18.8)$ & $7(9.1)$ & $21(18.9)$ \\
\hline $35-49$ & $11(18.3)$ & $18(18.4)$ & 0.613 \\
\hline $50-69$ & $33(31.5)$ & 0.005 & \\
\hline P-value & 0.125 & & \\
\hline
\end{tabular}


Page 17/17 